\title{
N-I-P MICROMORPH SOLAR CELLS ON ALUMINIUM SUBSTRATES
}

\section{M.GOETZ, P.TORRES, P.PERNET, J.MEIER, D.FISCHER, H.KEPPNER, A.SHAH}

Institut de Microtechnique (IMT) de l'Université de Neuchâtel, Rue Breguet 2, CH-2000 Neuchâtel, Switzerland, goetz@imt.unine.ch

\section{ABSTRACT}

The first successful deposition of 'micromorph' silicon tandem solar cells of the n-i-p-n-i-p configuration is reported. In order to implement the 'micromorph' solar cell concept, four key elements had to be prepared: First, the deposition of mid-gap, intrinsic microcrystalline silicon $(\mu \mathrm{c}-\mathrm{Si}: \mathrm{H})$ by the 'gas purifier method', second, the amorphous silicon (a-Si:H) n-i-p single junction solar cell, third, the microcrystalline silicon n-i-p single junction solar cell and fourth, the ability of depositing on aluminium sheet substrates.

All the solar cells presented have been deposited on flat aluminium sheets, using a single layer antireflection coating to couple the light into the cell. It is shown, that this antireflection concept- together with a flat substrate- holds for amorphous single junction solar cells, but it reaches its limit with the extended range of spectral response of the 'micromorph' cell.

The best initial efficiencies for each category of $n-i-p$ cells on flat substrates were: $8.7 \%$ for the amorphous silicon single junction cell, $4.9 \%$ for the microcrystalline silicon single junction cell and $9.25 \%$ for the 'micromorph' tandem cell.

\section{INTRODUCTION}

The mixed amorphous / microcrystalline tandem solar cell concept was introduced in 1994 [1] by our group (IMT). These so-called 'micromorph' cells are 'real' tandem cells, employing two materials of a different optical gap for the top and the bottom cell $(1.7 \mathrm{eV}$ and $1 \mathrm{eV}$, respectively [2]). The enhanced infrared absorption and the lack of light-induced degradation [3] of the microcrystalline silicon are successfully combined with the high $\mathrm{V}_{\mathrm{oc}}$ of the amorphous silicon solar cell. This lead sofar to solar cells of the $\mathrm{p}-\mathrm{i}-\mathrm{n}-\mathrm{p}-\mathrm{i}-\mathrm{n}$ superstrate structure on classical TCO on glass of a confirmed stabilised efficiency of $10.5 \%$ [4].

Conceptionally, cells of the p-i-n deposition order are limited to transparent substrates like glass or some (rare!) highly transparent and temperature resistant polymers, as the light always enters the cell through the substrate in this configuration. To be able to use a wider choice of substrates, including opaque metal sheets, the inverse $n-i-p$ deposition order has to be applied. In this case, the light enters the cell from the 'top' side, i.e. the side opposite to the substrate. One advantage of the $n-i-p$ configuration is the better control of the delicate $\langle p\rangle \mid\langle i\rangle$-interface, as it is deposited last, on the opposite side of the nucleation base [5]. Microcrystalline window layers are used more successfully in the n-i-p structure than in $\mathrm{p}-\mathrm{i}-\mathrm{n}$ cells, leading to high $\mathrm{V}_{\mathrm{oc}}$-values even without any buffer layer. In this study aluminium sheets are used as substrates. The long term goal is the direct integration of silicon thin film solar cells into a type of façade construction elements, which consists of an aluminium-polymer compound. This type of façade construction elements- but without the incorporated solar cell- is a standard commercial product of which millions of square meters have been sold [6]. Aluminium has also been chosen for its ductility which offers the (not yet employed) possibility of controlled geometrical texturing for 
improved light-trapping, allowing to deposit thinner and therefore more stable a-Si:H solar cells.

\section{EXPERIMENT AND RESULTS}

\section{Amorphous silicon $\mathrm{n}-\mathrm{i}-\mathrm{p}$ single junction solar cells}

To be able to deposit a-Si:H solar cells on commercial aluminium sheets, as was our aim, several substrate-related problems had to be solved. Metal diffusion from the substrate or from the back contact had to be suppressed by an antidiffusion layer, as is reported elsewhere [7]. Surface topography of the aluminium sheets turned out to be a hard problem. The surface of the metal sheet has to be treated in an appropriate way to avoid 'pinholes' in the solar cells or in general to get high values of parallel resistance.

In the $n-i-p$ configuration the top contact is deposited last. A thin film of Indium Tin Oxide (ITO) can serve as electrical contact and antireflection (AR) coating at the same time. An antireflection coating is always optimised for a certain wavelength and has a certain 'spectral width', i.e. a range of wavelength, where the reflectivity is actually reduced. In our first case, the flat cell of amorphous silicon, the minimum of reflection is set to 550nm and the important range (with respect to the spectral response curve of the cells) from 400 to $700 \mathrm{~nm}$ is more or less covered. The excellent coupling of the most important green light (reflectivity near $0 \%$ ) more than compensates the losses at the borders of the spectral range of the AR coating, where some of the blue and some of the red or infrared light is reflected. A flat cell of a thickness of 0.4 microns with a good back reflector and the presented AR coating, but without any further lighttrapping, furnishes about $15 \mathrm{~mA} / \mathrm{cm}^{2}$ at $\mathrm{I}_{\mathrm{sc}}$ conditions. It has an efficiency of more than $8 \%$.

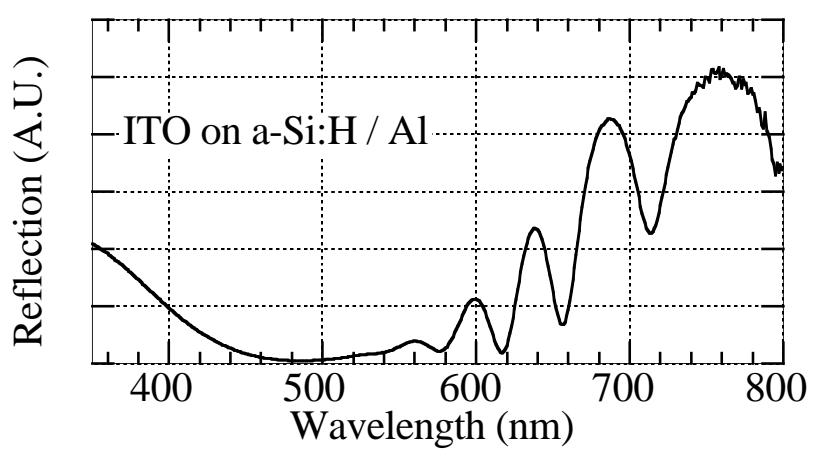

Figure 1. Reflection of an ITO antireflection coating on a-Si:H on a flat aluminium sheet vs. wavelength. The optimum in this example is set to about 500nm.

Note: A solar cell with this AR coating has a violet aspect; the colour violet is the sum of red and blue (reflected) light.

\section{Microcrystalline silicon n-i-p single junction solar cells}

Microcrystalline silicon, deposited without special precaution, has an n-type character. For a long time $\mu \mathrm{c}-\mathrm{Si}: \mathrm{H}$ was therefore not considered to be a potential candidate for an absorbing $<\mathrm{i}>-$ layer in a solar cell. By the 'microdoping' approach [8], a first microcrystalline 'mid-gap' material could be realised and first entirely microcrystalline silicon solar cells were deposited. In the meantime, it could be shown that the use of a gas purifier can replace the quite unreliable technique of 'microdoping' $[9,10]$. In the p-i-n configuration on textured glass / TCO substrates, efficiencies of $7.7 \%$ have been achieved by our group [9].

First entirely microcrystalline n-i-p cells on aluminium substrates have been deposited. Microcrystalline cells are very sensitive to contamination of the <i>-layer; as the pronounced effect of the gas purifier prooves. It is therefore surprising, that the same antidiffusion scheme, 
as has been introduced for the (less sensitive) amorphous silicon cells, also holds for the $\mu \mathrm{c}-$ $\mathrm{Si}: \mathrm{H}$ cells. The low contamination level allows one to deposit thick cells of up to 4 microns to obtain high short circuit currents. (Microcrystalline material deposited by the 'microdoping' technique limited the thickness of the cell to 2 microns [9].)

The absorption range of the microcrystalline cell is extended towards higher wavelengths compared to amorphous cells. For $\mu \mathrm{c}-\mathrm{Si}: \mathrm{H}$ solar cells, the thickness of the ITO antireflection layer should therefore be optimised to have its minimum of reflection at a higher wavelength than for a-Si:H cells. For the flat single junction microcrystalline cell of 4 microns thickness, with a good back reflector and an ITO AR layer, but without any further light trapping, a current density of $24 \mathrm{~mA} / \mathrm{cm}^{2}$ has been measured. The best efficiency of a $\mu \mathrm{c}-\mathrm{Si}: \mathrm{H} \mathrm{n}$-i-p cell on an aluminium substrate was sofar $4.9 \%$.

The microcrystalline silicon deposited by Very High Frequency -Glow Discharge (VHF-GD) has an enhanced absorption coefficient. Its absorption over the whole important wavelength range is higher than the absorption of crystalline silicon. The reason for the high absorption is still under discussion: strain-induced change of the absorption, the high relative number of silicon atoms at grain boundaries and light scattering within the film are probable explications $[11,4]$.

The films have a columnar structure [9] and- under certain deposition conditions- a 'milky' aspect. Further research should show, which factor of the deposition conditions is responsible for a higher or for a lower scattering coefficient of the films. For the solar cells presented, a microcrystalline material with high light scattering has been chosen. The comparison of the spectral response curve of an amorphous and a microcrystalline single-junction cell (figure 3, circles and squares) shows much more important interference fringes for the a-Si:H cell than for the $\mu \mathrm{c}-\mathrm{Si}: \mathrm{H}$ cell; the substrate is a flat aluminium sheet in both cases. The light seems to be scattered within the microcrystalline film, thereby reducing the effect of interference. (The rougher surface of the microcrystalline film compared to an amorphous film, however, could also be responsible for reduced interference). Scattering could act as 'internal' light trapping, enhancing the optical thickness of the cell, and this might be an important advantage of microcrystalline films. Deposition conditions could be optimised to get the highest scattering of the infrared light. (Note, however, that light scattering can only work on the fraction of the light, which has actually entered the solar cell. It has no effect on the surface of the cell. An effective AR coating still remains important.)

One drawback of the microcrystalline silicon <i>-layers is the rather low deposition rate (typically $1.2 \AA / \mathrm{sec}$ for VHF-GD), combined with the fact, that the cells are about 10 times thicker than their amorphous counterparts. Economic production needs short deposition times. For this reason, a big effort was undertaken to raise the deposition rate. The cells, which are presented here, were deposited at a rate of $4.3 \AA / \mathrm{sec}$ [12] and ongoing research promises even higher deposition rates $(9.4 \AA / \mathrm{sec}$ are reported in [13]).

\section{'Micromorph' silicon n-i-p-n-i-p heterojunction solar cells}

All the individual elements (a-Si:H n-i-p cell, $\mu \mathrm{c}-\mathrm{Si}: \mathrm{H}$ n-i-p cell and a tested substrate) were first tested and the whole 'micromorph' cell had then to be 'put together'. The two cells were deposited in different deposition chambers and the samples were transferred at the air. Some samples were even stored for one or two weeks between the two depositions. The inevitable native oxide layer on the bottom cell $(\mu \mathrm{c}-\mathrm{Si}: \mathrm{H})$ was not removed before deposition of the top cell (a-Si:H). Still, the tunnel junction between the two cells of the tandem worked well, and reasonable values of series resistance were measured. Both of the two adjacent layers of the 
tunnel junction $(<\mathrm{p}>$ of the bottom cell and $<\mathrm{n}>$ of the top cell) are microcrystalline layers, a combination which has been reported to be favourable for tunnel junctions [14].

First attempts to deposit the 'micromorph' solar cells were promising, leading to an initial efficiency of $9.25 \%$ on a flat substrate.

The 'micromorph' cell is a real tandem cell, employing materials of a different gap for the two cells. The advantage is, that a wider wavelength range of the sun's spectrum can be used by the cell. The 'micromorph' cell is sensitive from $350 \mathrm{~nm}$ up to more than $1000 \mathrm{~nm}$. The wider absorption range, however, forms a more stringent requirement for the antireflection concept. Our structure (a flat cell with a single layer AR coating) reached its limits. The wavelength range, which is covered by the ITO single layer AR coating is too small for the 'micromorph' cell. Possibilities to resolve this problem would be (expensive?) multilayer AR coatings with a wider range or combinations of the single layer AR coating with other light trapping features. Rather wide $\mathrm{V}$-grooves in the substrate with an angle of $90^{\circ}$ at the bottom, conformally covered with the solar cell $[15,16]$, for instance, would give every reflected photon a second chance to be coupled into the cell, leading to higher short circuit currents. The reflectivity $\mathrm{R}$ for each wavelength would be the square of its value without light trapping. (For example: if $\mathrm{R}$ at a certain wavelength without $\mathrm{V}$-groove is $20 \%$, then $\mathrm{R}$ with $\mathrm{V}$-grooves of $90^{\circ}$ is $20 \% \times 20 \%=$ $4 \%)$.

Typically, the optimisation of a tandem cell (p-i-n-p-i-n on glass / TCO) is a problem of two variables: the thickness of the top and the thickness of the bottom cell. The two thicknesses have to be adjusted to have equivalent currents in both cells; the top cell has to be thin enough to let enough light pass for the bottom cell. In our case, we can play on three variables: the thickness of the top cell, the thickness of the bottom cell and the thickness of the ITO layer. The last parameter moves the 'window' for best coupling of the light into the cell more towards one or more towards the other cell.

The first depositions showed that, for the current matching, we can aim on $24 \mathrm{~mA} / \mathrm{cm}^{2}$ of total current at $\mathrm{I}_{\mathrm{sc}}$ conditions, i.e. $12 \mathrm{~mA} / \mathrm{cm}^{2}$ for the top cell and $12 \mathrm{~mA} / \mathrm{cm}^{2}$ for the bottom cell. This total current is limited by the AR range of the ITO layer.

Sofar, the $\mathrm{I}_{\mathrm{sc}}$-values of bottom and top cell were not yet balanced $\left(11.1 / 13.1 \mathrm{~mA} / \mathrm{cm}^{2}\right)$. With a $\mathrm{V}_{\mathrm{oc}}$ of $1.24 \mathrm{~V}$ and a fill factor of $67.3 \%$ this still counts up to $9.25 \%$ initial efficiency. (With equal currents of $12.1 \mathrm{~mA} / \mathrm{cm}^{2}$ an initial efficiency of $10 \%$ would have been reached).

No degradation experiments have been done with these cells as yet. Still, it is obvious that we confront the same problem as has been described for the p-i-n-p-i-n cells in [3]: The microcrystalline bottom cell can reach very high current levels. Therefore the amorphous top cell, which does not profit of the back reflector as it does in a single junction device, must be rather thick to furnish the same current as the bottom cell in the tandem device. In our case, the top cell must have a thickness of about $3500 \AA$ to deliver $12 \mathrm{~mA} / \mathrm{cm}^{2}$ at $\mathrm{I}_{\mathrm{sc}}$ conditions. Cells of this thickness still suffer from pronounced degradation. (Note: only the top cell has to be considered for degradation, microcrystalline cells have shown to be stable even under very strong illumination [9]). In order to reduce degradation of the device, thinner amorphous cells would be preferable. Solutions like an interior mirror layer between the two cells to reduce the thickness of the top cell are discussed in [3]. The same concepts could be applied in the n-i-pn-i-p configuration. 


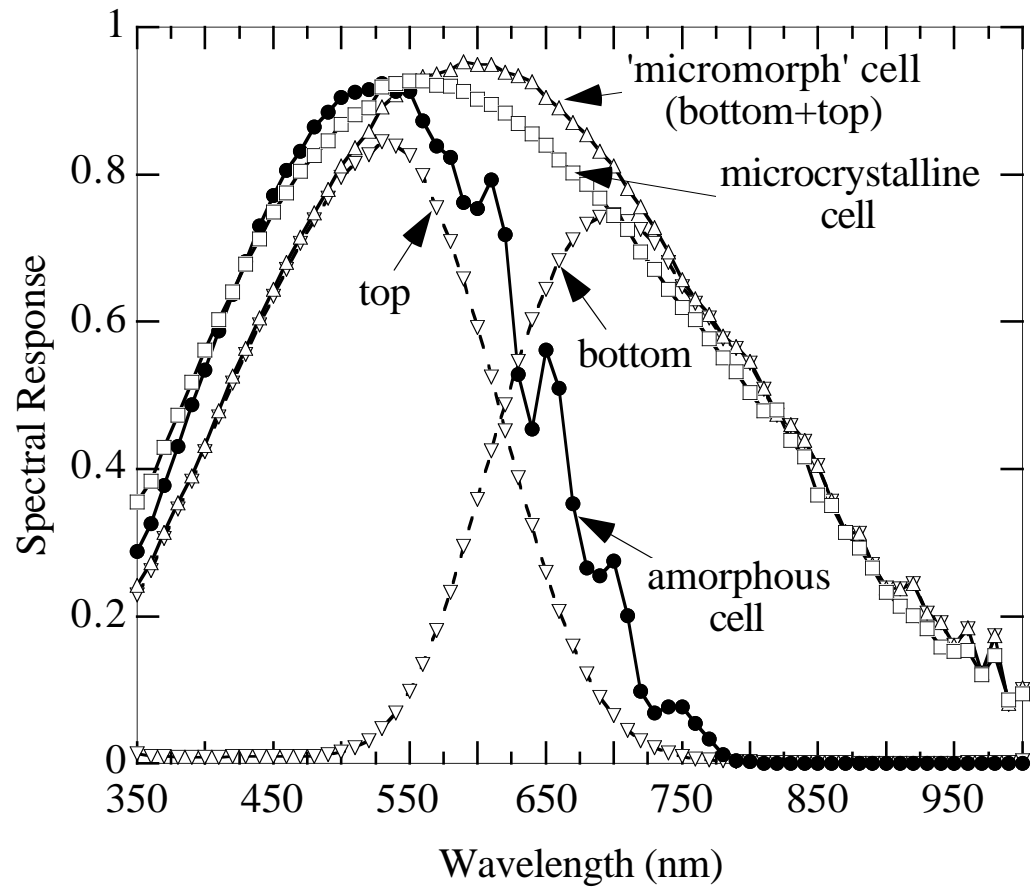

Figure 2. Spectral response curves for different types of solar cells on flat aluminium sheets:

dark circles $=$

amorphous cell

(AR range on the 'blue' side) white squares $=$ microcrystalline cell

(AR range on the 'blue' side) white triangles $=$

'micromorph' cell (top, bottom, bottom + top)

(AR range on the 'red' side)

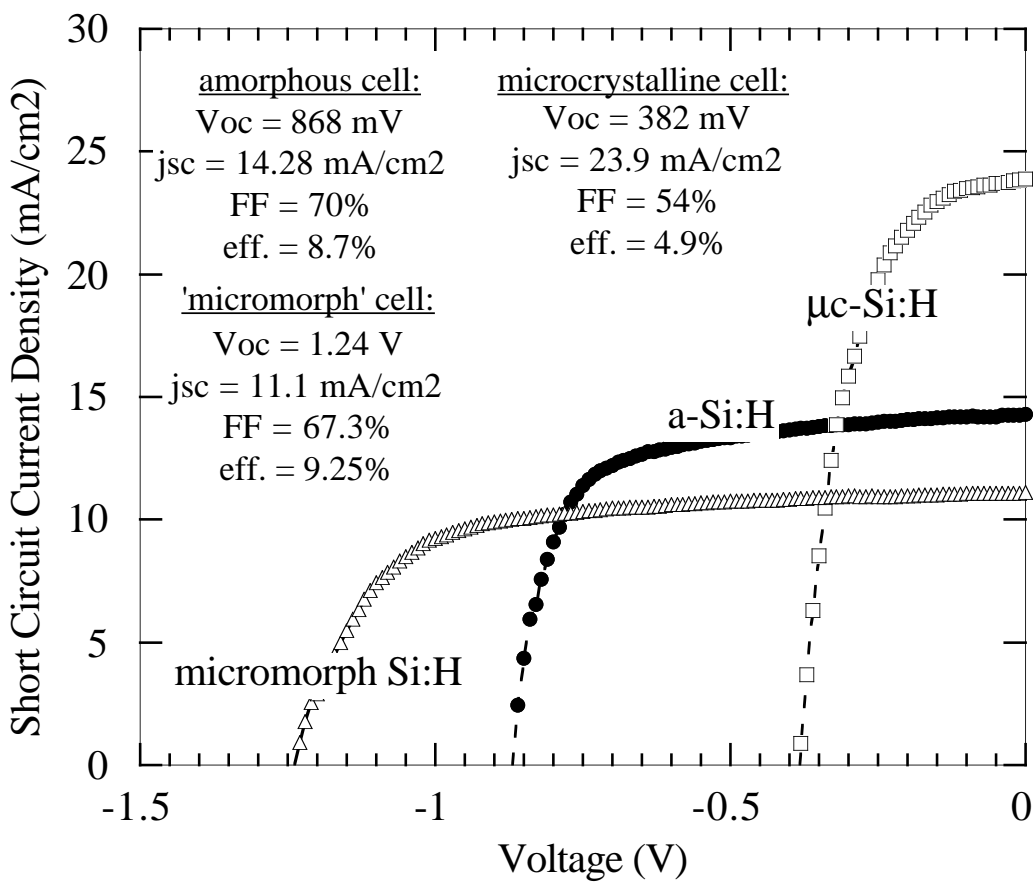

Figure 3. I(V)-characteristics for three types of solar cells on flat aluminium sheets: an amorphous cell, a microcrystalline cell and a 'micromorph' cell.

\section{CONCLUSIONS}

Several elements were needed for the successful deposition of the first 'micromorph' solar cells of the n-i-p-n-i-p configuration on flat aluminium sheets: First, the deposition of mid-gap, intrinsic microcrystalline silicon by the 'VHF-GD/gas purifier method', second, the amorphous $\mathrm{n}$-i-p single junction solar cell, third, the microcrystalline n-i-p single junction solar cell and fourth, the experience of depositing on aluminium sheets. 'Micromorph' solar cells of an efficiency of $9.25 \%$ could be realised, and this even without matched currents. It was found, that the tunnel junction between the two cells works well without any optimisation. From an optical 
point of view, it seems that light scattering within the microcrystalline bottom cell acts as 'internal light-trapping', enhancing the optical thickness of the flat solar cells. On the other hand, the applied single-layer antireflection coating has too small a spectral range for this type of solar cells, as these cells are sensitive to a wide spectral range of light from $350 \mathrm{~nm}$ to more than $1000 \mathrm{~nm}$. Therefore, a multilayer AR coating or supplementary light trapping schemes would be needed to take advantage of the full range of light, to which the 'micromorph' cell is sensitive.

\section{ACKNOWLEDGEMENTS}

This work has been supported by the Swiss National Energy Research Foundation under grant NEFF 682 and by the Swiss Federal Office of Energy (OFEN) under contract EF-REN (93) 032. We would like to thank Alusuisse Technology \& Management Ltd. for supplying the aluminium substrates.

\section{REFERENCES}

1. J. Meier, S.Dubail, R.Flückiger, D.Fischer, H.Keppner, A.Shah, 1st WCPEC, Waikoloa, Hawaii, Dec. 5-9, 1994

2. D.Fischer, S.Dubail, J.A.Anna Selvan, N.Pellaton Vaucher, R.Platz, Ch. Hof, U.Kroll, J.Meier, P.Torres, H.Keppner, N.Wyrsch, M.Goetz, A.Shah, K.-D.Ufert, 25th IEEE PV Spec. Conf., Washington, 1996

3. J.Meier, S.Dubail, D.Fischer, J.A.Anna Selvan, N. Pellaton Vaucher, R.Platz, Ch.Hof, R.Flückiger, U.Kroll, N.Wyrsch, P.Torres, H.Keppner, A.Shah, K.-D.Ufert, 13th European Photovoltaic Solar Energy Conference, Nice, 1995, p.1445-1450

4. J.Meier, P.Torres, R.Platz, S.Dubail, U.Kroll, J.A.Anna Selvan, N. Pellaton Vaucher, Ch.Hof, D.Fischer, H.Keppner, A.Shah, K.-D.Ufert, PVSEC-9, Miyazaki, 1996

5. P.Pernet, M.Goetz, H.Keppner, A.Shah, this conference

6. M.Wuest, P.Toggweiler, 1st WCPEC, Waikoloa, Hawaii, Dec. 5-9, 1994

7. M.Goetz, H.Keppner, P.Pernet, W.Hotz, A.Shah, MRS 1996 spring meeting, San Francisco

8. R.Flückiger, J.Meier, M.Goetz, A.Shah, J.Appl.Phys. 77 (2), 15 January 1995, p.712716

9. J.Meier, P.Torres, R.Platz, S.Dubail, U.Kroll, J.A.Anna Selvan, N.Pellaton Vaucher, Ch.Hof, D.Fischer, H.Keppner, A.Shah, K.-D.Ufert, P.Giannoulès, J.Koehler, MRS 1996 spring meeting, San Francisco

10. P.Torres, J.Meier, R.Flückiger, U.Kroll, J.A. Anna Selvan, H.Keppner, A.Shah, S.D. Littlewood, I.E. Kelly, P. Giannoulès, Appl. Phys. Lett. 69 (10), 2 September 1996

11. N.Beck, J.Meier, J.Fric, Z.Remes, A.Poruba, R.Flückiger, J.Pohl, A.Shah, M.Vanecek, J. of non-cryst. solids, 198-200 (1996), p.903-906

12. P.Torres, J.Meier, M.Goetz, U.Kroll, H.Keppner, A.Shah, this conference

13. H.Keppner, U.Kroll, P.Torres, J.Meier, R.Platz, D.Fischer, S.Dubail, J.A.Anna Selvan, N.Pellaton Vaucher, Y.Ziegler, R.Tscharner, Ch.Hof, N.Beck, M.Goetz, P.Pernet, M.Goerlitzer, N.Wyrsch, A.Shah, J.Pohl, E.Bucher, this conference

14. T.Yoshida, K.Maruyama, O.Nabeta, V.Ichikawa, H.Sakei, Y.Uchida, 19th IEEE PV Spec. Conf., 1987, p.1095-1100

15. G.Schumm, H.-D.Mohring, G.H.Bauer, 11th Photovoltaic Solar Energy Conference, Montreux, Oct. 12-16,1992, p.207-210

16. D.Thorp, P.Campbell, S.Wenham, 25th IEEE PV Spec. Conf., Washington, 1996 